\title{
Penentuan Potensi Sumberdaya Batu Gamping Sebagai Bahan Baku Semen Daerah Gandu Dan Sekitarnya, Kecamatan Bogorejo, Kabupaten Blora, Jawa Tengah
}

\author{
Dian Agus Widiarso*, Istiqomah Ari Kusuma, Ajiditya Putro F \\ Departemen Teknik Geologi, Fakultas Teknik, Universitas Diponegoro, \\ Jl. Prof. Soedarto, SH, Kampus Undip Tembalang, Semarang, Indonesia 50275
}

\begin{abstract}
Abstrak
Kebutuhan pembangunan infrastruktur selalu meningkat seiring dengan pertumbuhan penduduk. Industri konstruksi membutuhkan batugamping yang merupakan bahan pembuatan semen untuk pondasi konstruksi bangunan. Salah satu daerah yang memiliki potensi batu gamping adalah daerah Gandu, Kecamatan Bogorejo, Blora, Jawa Tengah. Penelitian ini bertujuan untuk melakukan eksplorasi potensi batu gamping di daerah Gandu. Pemetaan geologi dilakukan untuk menentukan litologi utama daerah penelitian dan distribusinya. Analisis kualitas batugamping juga dilakukan dalam penelitan ini, dengan mengkaji komposisi kimia batugamping. Diharapkan hasil penelitian ini dapat digunakan sebagai dasar pemanfaatan batugamping untuk kebutuhan industry semen. Hasil penelitian menunjukkan bahwa stratigrafi regional area penelitian terdiri dari empat satuan batuan, yaitu batulempung karbonan, batugamping, kristalin batupasir kuarsa, dan batugamping. Hasil penelitian juga menunjukkan bahwa batugamping dari daerah Gandu memiliki unsur CaO cukup besar dan unsur Mg sedikit, walaupun di beberapa tempat banyak ditemukan unsur Mg. Perbandingan hasil analisis komposisi kimia dan standar bahan baku semen menunjukkan bahwa kapur di daerah Gandu memenuhi kriteria bahan baku semen.
\end{abstract}

Kata kunci: Sumber Daya Alam, Semen, Batugamping

\begin{abstract}
[Potential Identification of Limestone Resources for Cement Material In Gandu Area, Bogorejo, Blora District, Central Java] The growing number of population, demands infrastructure development. Construction industries need limestones which is used as the main material for cement. Gandu which is located in Distric Bogorejo, Blora, Central Java has the potential of natural limestones.This study was conducted by doing field observation for geological mapping to determine the main lithology as well as materials distribution. Chemical analysis to limestone was also done to measure the quality. It is hoped that the result of the study can be used to support the use of limestones for the cement industry. The result of the study showed that the area consist of four rocks unit: carbonaceous claystone unit, quartz sandstone unit, , and chrystaline limestones unit, and limestones unit. The result of the study also showed that limestones from Gandu has a fairly large amount of $\mathrm{CaO}$ and a few $\mathrm{Mg}$ element. However, $\mathrm{Mg}$ was found in several locations. Based on the chemical composition standard of raw cement materials, limestone in the area met the criteria of raw cement material.
\end{abstract}

Keywords: Natural Resources, Cement, Limestones

\section{Pendahuluan}

Pertumbuhan jumlah penduduk Indonesia terus meningkat. Hasil kajian yang dilakukan oleh Badan Pusat Statistik (BPS), bekerja sama dengan The Australian National University (ANU), Lembaga Demografi Universitas Indonesia (LDUI), dan Australian Overseas

\footnotetext{
*) Penulis Korespondensi.

E-mail: dianagusgeo@gmail.com
}

Aid Program (AusAID) memproyeksikan jumlah penduduk Indonesia mencapai 273,2 juta pada tahun 2025 (Atmojo, 2013). Angka ini meningkat jauh dari data penduduk tahun 2000 yang berjumlah 205,1 juta. Peningkatan jumlah penduduk ini menyebabkan semakin besarnya kebutuhan akan perumahan. Pemenuhan kebutuhan perumahan menyebabkan peningkatan kebutuhan semen dan bahan bakunya. Untuk mengantisipasi kebutuhan ini maka diperlukan eksplorasi pencarian bahan semen, termasuk batugamping, yang merupakan bahan baku utama semen. 
Salah satu daerah yang memiliki potensi batugamping adalah desa Gandu, desa Tahunan, dan sekitarnya, yang berada di wilayah kecamatan Bogorejo (Badan Perencanaan Pembangunan Daerah Pemerintah Kabupaten Blora, 2016), kabupaten Blora, Jawa Tengah. Lokasi ini yang memiliki potensi batu gamping karena termasuk dalam Formasi Bulu yang terdiri dari litologi batugamping pasiran dan kalkarenit, dengan koordinat $\mathrm{N}$ 557000 - 564000 dan E 9234700 - 9238700.

Beberapa peneliti telah melakukan kajian tentang batugamping di daerah kabupaten Blora. Gana, Prasetyadi dan Triwibowo (2012) melakukan kajian geologi dan facies batugamping di desa Jurangrejo. Hasil penelitian menunjukkan litofasies batugamping Bulu terdiri dari boundstone (red algae framestone), mudstone, larger foram rudstone, dan red algae floatstone. Penyebaran litofasies didominasi oleh mudstone pada bagian selatan dan red algae floatstone pada bagian utara.

Prasetya (2015) melakukan penelitian di sekitar Desa Kajar, Desa Tegaldowo, Kecamatan Gunem, Kabupaten Rembang dan Desa Jurangjero, Desa Gandu Kecamatan Bogorejo, Kabupaten Blora. Penelitian ini dilakukan untuk mengetahui kandungan unsur $\mathrm{MgO}$ atau dolomit pada batugamping. Kondisi geomorfologi di daerah ini terdiri dari dua bentuk lahan yaitu bentuk lahan karst antiklin sinklin dan perbukitan karst zona sesar dengan pola pengaliran dendritik dan jenis sungai periodik. Daerah penelitian terdiri dari Formasi Bulu yang tersusun oleh batugamping berlapis, bersisipan batupasir dan batulempung yang berumur Miosen Tengah dan Formasi Paciran yang tersusun oleh batugamping terumbu masif berumur Pliosen Awal-Plistosen, sehingga hubungan kedua Formasi tersebut merupakan ketidakselarasan. Struktur geologi yang dijumpai berupa kekar dengan arah umum baratdaya-timurlaut dan tenggara-baratlaut. Terdapat 6 sesar mendatar yang relatif berarah umum barat-timur, baratdaya-timurlaut, dan tenggarabaratlaut. Lipatan terdiri dari sinklin dengan arah umum tenggara-baratlaut dan baratdaya-timurlaut serta antiklin dengan arah umum tenggara-baratlaut.

Penelitian ini dilakukan dengan menganalisis lebih terperinci kualitas berdasar komposisi kimia batugamping berupa $\mathrm{Al}_{2} \mathrm{O}_{3}, \mathrm{SiO}_{2}, \mathrm{CaO}, \mathrm{Fe}_{2} \mathrm{O}_{3}, \mathrm{MgO}$ dan $\mathrm{H}_{2} \mathrm{O}$ berikut prospek pemanfaatan batugamping untuk industri semen. Diharapkan penelitian ini dapat melengkapi penelitian yang telah dilakukan oleh para peneliti sebelumnya.

\section{Bahan dan Metode}

Pengumpulan data penelitian dilakukan untuk mendapatkan data geologi secara terperinci. Data yang dikumpulkan dalam penelitian ini meliputi data primer dan data sekunder. Data primer berupa pemetaan geologi, sedangkan data sekunder berupa data analisis kimia hasil pengamatan unsur kimia pada batuan menggunakan $X$ Ray Fluorescence (XRF) untuk mengetahui komposisi $\mathrm{Al}_{2} \mathrm{O}_{3}, \mathrm{SiO}_{2}, \mathrm{CaO}, \mathrm{Fe}_{2} \mathrm{O}_{3}, \mathrm{MgO}$ dan $\mathrm{H}_{2} \mathrm{O}$ batugamping daerah tersebut. Analisis kualitas batugamping dilakukan berdasarkan data kandungan unsur kimia batugamping. Hasil analisis ini menjadi dasar untuk melihat kualitas batugamping sebagai bahan industry semen berdasarkan kondisi geologi dan komposisi batugamping.

\section{Hasil dan Pembahasan Stratigrafi Daerah Penelitan}

Daerah penelitian ini termasuk ke dalam Zona Rembang yang didominasi oleh satuan batuan yang memiliki umur relatif Miosen (Van Bemmelen, 1949). Stratigrafi daerah pemetaan tersusun oleh empat satuan batuan (Gambar 1).

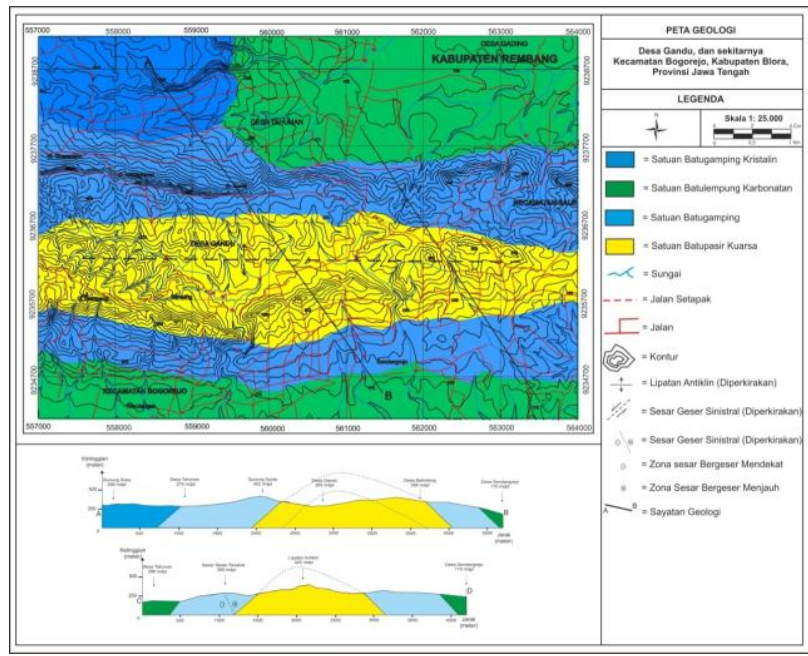

Gambar 1. Peta Geologi Daerah Gandu

\section{a. Batupasir Kuarsa}

Batupasir Kuarsa berada pada bagian tengah lokasi penelitian dan mencakup $\pm 20 \%$ dari luas keseluruhan daerah penelitian. Satuan ini tersingkap di daerah Desa Gandu, Blimbing dan Gunung Gampeng. Satuan ini terdiri atas batupasir kuarsa, yang memiliki karakteristik warna segar putih kekuningan dan warna lapuk kuning kecoklatan gelap. Selain itu, satuan ini memiliki karakteristik besar butir pasir sedang-pasir halus, menyudut tanggung-membundar tanggung, pemilahan baik, kemas tertutup, lapuk $20 \%$, didominasi mineral kuarsa, dan dijumpai struktur paralel laminasi, gradded bedding (Gambar 2) serta terdapat struktur perlapisan. Satuan Batuan ini memiliki jurus lapisan umum berarah barat-timur sampai baratlaut-tenggara dengan kemiringan lapisan berkisar antara $15^{\circ}$ hingga $24^{\circ}$.

Pada singkapan batupasir kuarsa tersebut terdapat sisipan batugamping pasiran (Gambar 3) yang memiliki karakteristik berwarna kecoklatan, terdiri dari material karbonat, foraminifera besar, memiliki ukuran butir pasir sedang hingga pasir kasar $(1 / 4-1 \mathrm{~mm})$ dengan tingkat kebundaran yang sub angular hingga sub rounded, kompak, kemas terbuka serta sortasi buruk. Kuarsa 
Teknik, 38 (2), 2017, 94

ditemukan di batulempung karbonatan dengan warna coklat-keabuan dengan kedudukan N117 E/ $29^{\circ}$.

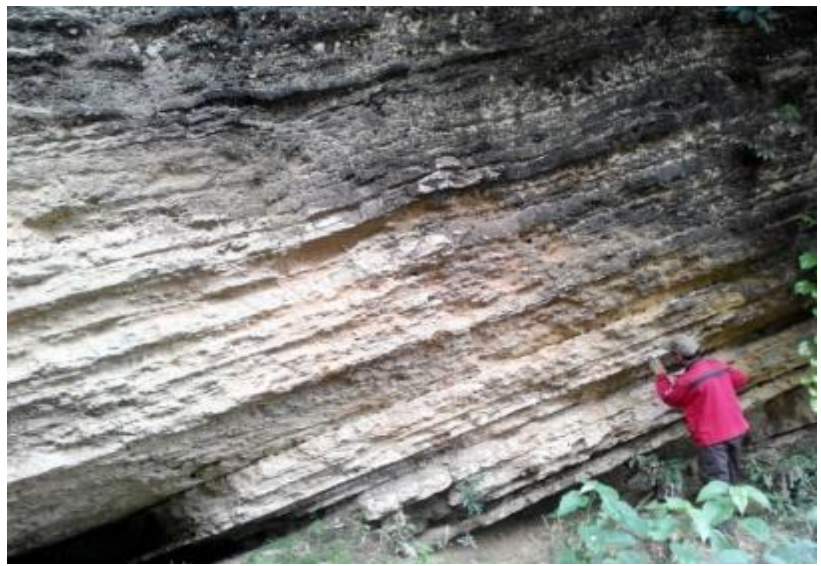

Gambar 2. Singkapan Batupasir Kuarsa

Batu ini tersusun dari butiran lempung $1 / 256 \mathrm{~mm}$, sifat non-karbonatan, tingkat kekompakan sedang, lapuk tinggi, sortasi sedang, kemas tertutup. Pringgoprawiro (1983) menyatakan bahwa Satuan Batupasir Kuarsa termasuk dalam Formasi Ngrayong dan diendapkan selaras di atas Formasi Tawun yang berumur Miosen Tengah (N9-N11).

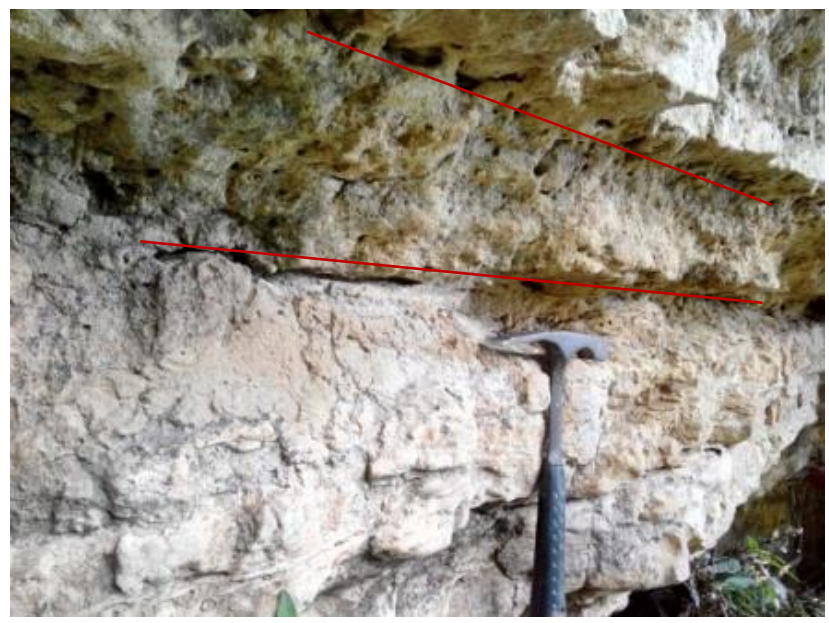

Gambar 3. Singkapan Batupasir Sisipan Batugamping Pasiran

\section{b. Satuan Batugamping}

Satuan Batugamping pasiran tersingkap baik di daerah Utara Desa Gandu, Ngajaran, Sendangrejo, Gunung Guaranjam, Gunung Keminkerep, Gunung Surak, menempati $\pm 30 \%$ dari luas keseluruhan daerah penelitian (Gambar 4). Satuan ini memiliki jurus lapisan umum berarah barat-timur sampai barat laut-tenggara dengan kemiringan lapisan berkisar antara $15^{\circ}$ hingga $24^{\circ}$. Kedudukan batuan yang terukur di lapangan sebesar $\mathrm{N} 119^{\circ} \mathrm{E} / 15^{\circ}$.

Batugamping ini memiliki warna segar putih keabu-abuan hingga kuning kecoklatan, dan warna lapuk abu-abu kecoklatan untuk warna lapuk, kemas tertutup, pemilahan baik grainsupported, terdiri atas red algae, foraminifera planktonik dan bentonik, foraminifera besar, fragmen litik (1 mm), kompak dan batugamping grainstone (Embry, Klovan, 1971). Satuan Batugamping ini diendapkan secara selaras di atas Satuan Batupasir Kuarsa Formasi Ngrayong, termasuk dalam Formasi Bulu dan memiliki umur Miosen Awal bagian akhirMiosen Tengah (Pringgoprawiro, 1983).

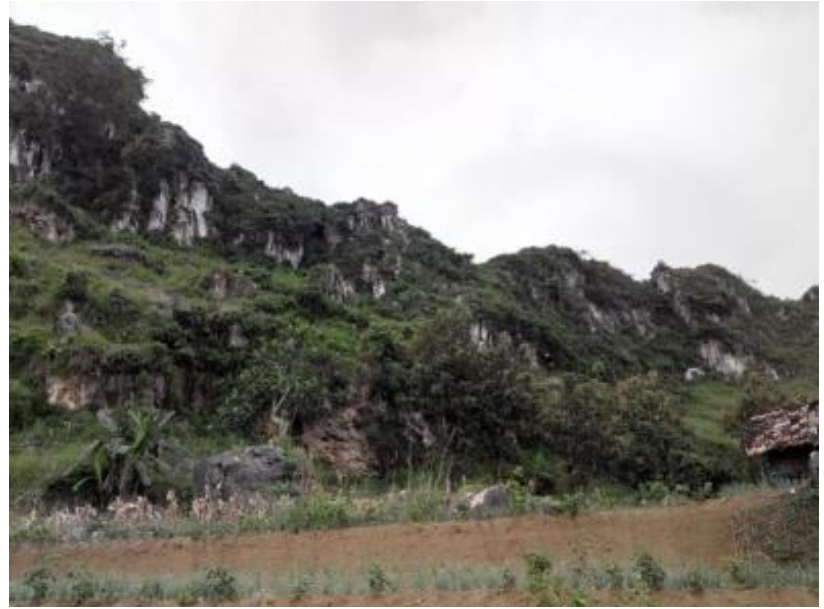

Gambar 4. Batugamping pada Daerah Gandu

c. Satuan Batulempung Karbonat

Satuan Batulempung Karbonatan menempati meliputi $\pm 20 \%$ daerah penelitian. Ini tersingkap baik di daerah Desa Gading, Tahunan, Sumberwungu, Wanutengah, dan Desa Sendangrejo.

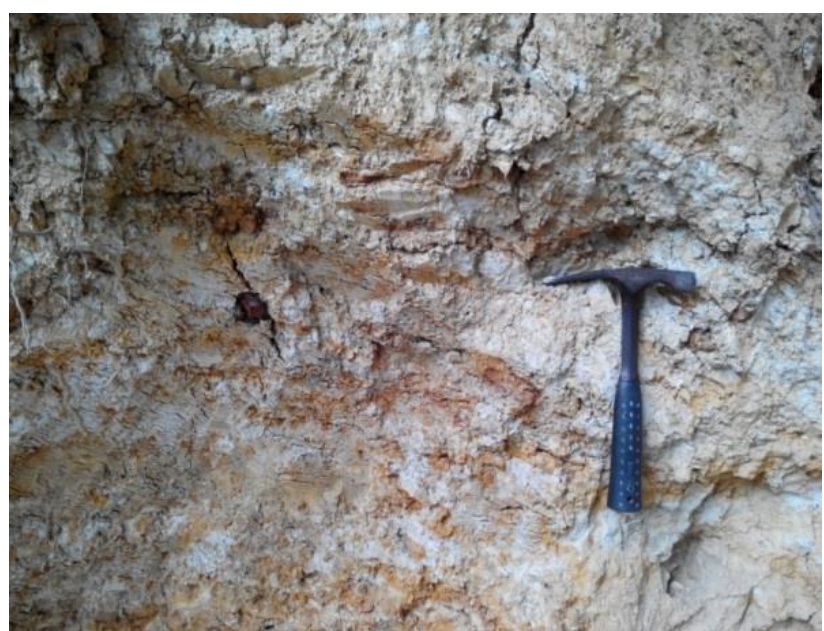

Gambar 5. Batulempung Karbonatan di daerah Tahunan

Satuan Batulempung karbonatan, warna segar coklat keputihan dan warna lapuk coklat kehijauan, bertekstur klastik, bersifat karbonatan, dijumpai foraminifera kecil dan serpihan cangkang disisipan batugamping Packstone (Embry, Klovan, 1971) (Gambar 5 dan Gambar 6), grainsupported, kuning kecoklatan, 
kemas tertutup, pemilahan sedang, dijumpai foraminifera kecil dan pecahan cangkang. Batulempung karbonat tersebut termasuk dalam Formasi Wonocolo diperkirakan berumur Miosen Akhir bagian bawah sampai tengah Pringgoprawiro (1983).

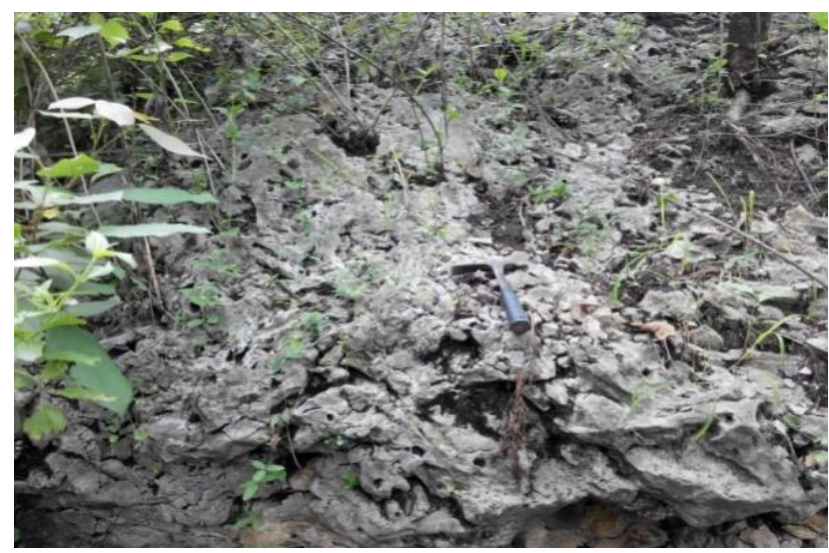

Gambar 6. Singkapan Batugamping di daerah Tahunan

\section{d. Satuan Batugamping Kristalin}

Satuan Batugamping kristalin ini secara megaskopis berwarna putih kecoklatan untuk batuan yang segar dan coklat untuk batuan yang lapuk, ukuran butir pasir sedang sampai kasar $(1-1 / 4 \mathrm{~mm})$ Skala Wentworth tekstur berupa kristalin, struktur yang masif, sirtasi buruk, kemas terbuka. Komposisi mineral yang ada berupa kalsit dan dolomit. Satuan Batugamping kristalin menempati \pm $15 \%$ dari luas keseluruhan daerah penelitian dan menempati bagian selatan daerah penelitian (Gambar 7). Satuan ini tersingkap baik di daerah utara Gunung Payung, Gunung Suka, Desa Tahunan.

Dengan tidak adanya foraminifera besar Heterostegina sp menandakan bahwa Satuan Batugamping kristalin ini berumur lebih muda dari Miosen termasuk dalam Formasi Paciran (Pringgoprawiro, 1983).

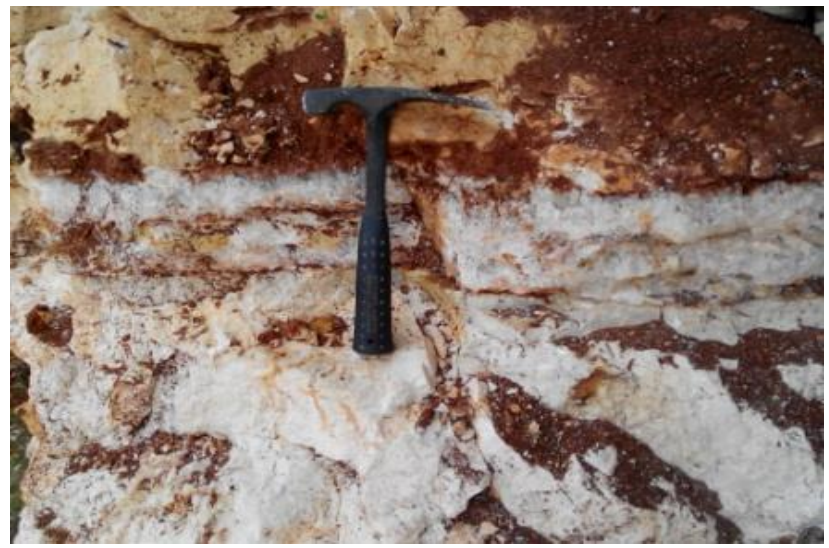

Gambar 7. Batugamping Kristalin di Desa Kajar

\section{Analisis kimia Batugamping Formasi Bulu}

Salah satu cara untuk mengetahui kualitas batuan karbonat khususnya batugamping untuk bahan baku semen adalah dengan menggunakan data analisis kimia. Batugamping yang diambil sampelnya secara terukur meliputi lokasi Daerah Gandu (Gambar 8). Sampel dianalisa di Laboratorium Pusat Sumber Daya Geologi. Contoh batuan yang diambil pada Daerah Gandu sebanyak 10 buah. Adapun senyawa yang dianalisis meliputi meliputi komposisi $\mathrm{Al}_{2} \mathrm{O}_{3}, \mathrm{SiO}_{2}, \mathrm{CaO}, \mathrm{Fe}_{2} \mathrm{O}_{3}$, $\mathrm{MgO}$ dan $\mathrm{H}_{2} \mathrm{O}$.

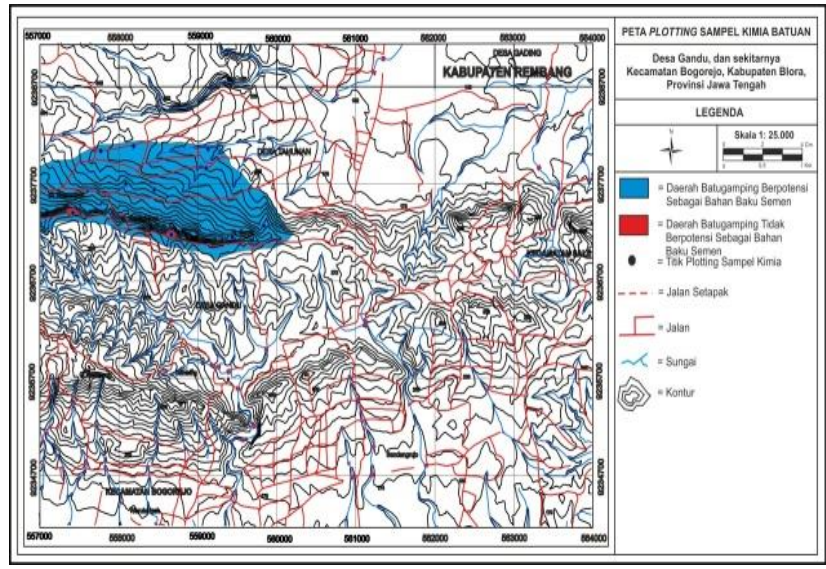

Gambar 8. Peta Plotting Sampel Analisis Kimia

Batugamping daerah penelitian mempunyai nilai $\mathrm{CaO}$ besar dan $\mathrm{Mg}$ sedikit. Hasil ini diperbandingkan dengan persyaratan yang telah diatur oleh beberapa perusahaan semen tersendiri dengan Standar Industri Indonesia (SII) untuk mengetahui kelayakan batugamping.

Komposisi kimia batugamping dipengaruhi oleh mineral dan komposisi organisme. Mineral kalsit terdiri dari dua macam, yaitu : (1) Low-Mg calcite, jika dibentuk pada derah dingin dan komposisi $\mathrm{MgCO}_{3}<4 \%$, (2) High$\mathrm{Mg}$ calcite dibentuk pada daerah hangat dengan komposisi $\mathrm{MgCO}_{3}>4 \%$. Hasil dari analisis kimia yang telah diolah dari laboratorium terlihat pada Tabel 1. 
Teknik, 38 (2), 2017, 96

Tabel 1. Hasil Analisis Kimia Batuan Karbonat pada Daerah Gandu

\begin{tabular}{|c|c|c|c|c|c|c|c|}
\hline $\begin{array}{l}\text { Kode } \\
\text { Conto }\end{array}$ & & $\mathrm{SiO}_{2}$ & $\mathrm{Al}_{2} \mathrm{O}_{3}$ & $\mathrm{Fe}_{2} \mathrm{O}_{3}$ & $\mathrm{CaO}$ & MgO & $\mathrm{H}_{2} \mathrm{O}$ \\
\hline & Metode & $\begin{array}{l}\text { K-III- } \\
32-03 \\
\text { IKNL }\end{array}$ & \multicolumn{5}{|c|}{ SNI 7574-2010 } \\
\hline & Koordinat & & & & & & \\
\hline AY 76 & $\begin{array}{l}0559014 \\
9238127\end{array}$ & 0,98 & 0,11 & 0,16 & 51,20 & 0,23 & 0,08 \\
\hline D 65 & $\begin{array}{l}0558568 \\
9237300\end{array}$ & 0,74 & 0,98 & 0,59 & 31,56 & 20,06 & 0,25 \\
\hline D 70 & $\begin{array}{l}0559302 \\
9237276 \\
\end{array}$ & 0,23 & 0,91 & 1,90 & 49,91 & 0,77 & 0,12 \\
\hline D 73 & $\begin{array}{l}0559675 \\
9237383 \\
\end{array}$ & 0,57 & 0,34 & 0,00 & 48,94 & 0,36 & 0,13 \\
\hline D 79 & $\begin{array}{l}0558034 \\
9237787\end{array}$ & 1,57 & 0,49 & 0,12 & 52,81 & 0,5 & 0,13 \\
\hline D 81 & $\begin{array}{l}0558373 \\
9237733\end{array}$ & 1,84 & 0,62 & 0,36 & 50,55 & 0,36 & 0,12 \\
\hline D 85 & $\begin{array}{l}0558989 \\
9237940 \\
\end{array}$ & 0,35 & 0,48 & 0,27 & 51,52 & 0,25 & 0,10 \\
\hline MB 93 & $\begin{array}{l}0557735 \\
9238106 \\
\end{array}$ & 0,21 & 0,29 & 0,21 & 48,62 & 0,89 & 0,03 \\
\hline MB 95 & $\begin{array}{l}0558126 \\
9238153 \\
\end{array}$ & 0,08 & 0,47 & 0,92 & 53,77 & 0,63 & 0,13 \\
\hline P 84 & $\begin{array}{l}0557401 \\
9237508 \\
\end{array}$ & 0,71 & 1,79 & 1,43 & 31,32 & 18,41 & 0,07 \\
\hline
\end{tabular}

\section{Kualitas Batugamping Untuk Bahan Baku Semen}

Kualitas batugamping Formasi Bulu di Daerah Gandu dapat dilihat dari hasil analisis komposisi kimia ditunjukkan pada Tabel 2 hingga Tabel 10. SII dijadikan sebagai standar acuan persyaratan komposisi kimia batugamping untuk bahan baku semen di Indonesia.

1. Hasil analisis komposisi kimia conto AY-76 pada koordinat (0559014, 9238127)

Berdasar Tabel 2, conto AY-76 memenuhi syarat kadar $\mathrm{SiO}_{2}, \mathrm{CaO}, \mathrm{MgO}, \mathrm{H}_{2} \mathrm{O}$ dalam kisaran yang telah ditentukan. Kadar $\mathrm{Al}_{2} \mathrm{O}_{3}$ danFe ${ }_{2} \mathrm{O}_{3}$ tidak memenuhi standar baku tapi memenuhi standar PT. Semen Padang sehingga dapat dipergunakan sebagai bahan baku semen.

Tabel 2. Pengklasifikasian Conto AY-76

\begin{tabular}{cccc}
\hline $\begin{array}{c}\text { Komposisi } \\
\text { Kimia } \\
\text { Batuan }\end{array}$ & $\begin{array}{c}\text { Conto } \\
\text { AY-76 }\end{array}$ & $\begin{array}{c}\text { Standar Bahan } \\
\text { Baku Semen } \\
\text { (Duda, 1976) }\end{array}$ & $\begin{array}{c}\text { Standar Bahan } \\
\text { Baku Semen } \\
\text { PT. Semen } \\
\text { Padang }\end{array}$ \\
\hline $\mathrm{SiO}_{2}$ & $0,98 \%$ & $0,76-4,75 \%$ & Maks. 5\% \\
$\mathrm{Al}_{2} \mathrm{O}_{3}$ & $0,11 \%$ & $0,71-2,00 \%$ & \\
$\mathrm{Fe}_{2} \mathrm{O}_{3}$ & $0,16 \%$ & $0,36-1,47 \%$ & \\
$\mathrm{CaO}$ & $51,2 \%$ & $49,8-55,6 \%$ & Min. 48\% \\
$\mathrm{MgO}$ & $0,23 \%$ & $0,30-1,48 \%$ & \\
$\mathrm{H} 2 \mathrm{O}$ & $0,08 \%$ & & Maks. 6\% \\
\hline
\end{tabular}

2. Hasil analisis komposisi kimia conto D-70 pada koordinat $(0559302,9237276)$

Conto D-70 memiliki kadar $\mathrm{CaO}, \mathrm{MgO}, \mathrm{H}_{2} \mathrm{O}, \mathrm{Al}_{2} \mathrm{O}_{3}$ dan $\mathrm{Fe}_{2} \mathrm{O}_{3}$ yang sesuai persyaratan yang telah ditentukan. Kadar $\mathrm{SiO}_{2}$ tidak masuk dalam kisaran standar baku semen, tetapi memenuhi syarat bahan baku semen dari PT. Semen Padang sehingga conto D-70 bisa dimanfaatkan sebagai bahan baku semen (Tabel 3).
Tabel 3. Pengklasifikasian Conto D-70

\begin{tabular}{cccc}
\hline $\begin{array}{c}\text { Komposisi } \\
\text { Kimia } \\
\text { Batuan }\end{array}$ & $\begin{array}{c}\text { Conto } \\
\text { D-70 }\end{array}$ & $\begin{array}{c}\text { Standar Bahan } \\
\text { Baku Semen } \\
\text { (Duda, 1976) }\end{array}$ & $\begin{array}{c}\text { Standar Bahan } \\
\text { Baku Semen PT. } \\
\text { Semen Padang }\end{array}$ \\
\hline $\mathrm{SiO}_{2}$ & $0,23 \%$ & $0,76-4,75 \%$ & Maks. 5\% \\
$\mathrm{Al}_{2} \mathrm{O}_{3}$ & $0,91 \%$ & $0,71-2,00 \%$ & \\
$\mathrm{Fe}_{2} \mathrm{O}_{3}$ & $1,90 \%$ & $0,36-1,47 \%$ & \\
$\mathrm{CaO}$ & $49,91 \%$ & $49,8-55,6 \%$ & Min. 48\% \\
$\mathrm{MgO}$ & $0,77 \%$ & $0,30-1,48 \%$ & \\
$\mathrm{H}_{2} \mathrm{O}$ & $0,12 \%$ & & Maks. 6\% \\
\hline
\end{tabular}

3. Hasil analisis komposisi kimia conto D-73 pada koordinat $(0559675,9237383)$

Conto D-73 memiliki kadar $\mathrm{MgO}, \mathrm{H}_{2} \mathrm{O}$ sesuai persyaratan bahan baku semen. Hasil analisis komposisi kimia juga menunjukkan bahwa kadar $\mathrm{Al}_{2} \mathrm{O}_{3}, \mathrm{SiO}_{2}, \mathrm{CaO}$, dan $\mathrm{Fe}_{2} \mathrm{O}_{3}$ memenuhi standar baku untuk semen dan dapat dimanfaatkan karena memenuhi persyaratan PT. Semen Padang (Tabel 4).

Tabel 4. Pengklasifikasian Conto D-73

\begin{tabular}{cccc}
\hline $\begin{array}{c}\text { Komposisi } \\
\text { Kimia } \\
\text { Batuan }\end{array}$ & $\begin{array}{c}\text { Conto } \\
\text { D-73 }\end{array}$ & $\begin{array}{c}\text { Standar Bahan } \\
\text { Baku Semen } \\
\text { (Duda, 1976) }\end{array}$ & $\begin{array}{c}\text { Standar Bahan } \\
\text { Baku Semen PT. } \\
\text { Semen Padang }\end{array}$ \\
\hline $\mathrm{SiO}_{2}$ & $0,57 \%$ & $0,76-4,75 \%$ & Maks. 5\% \\
$\mathrm{Al}_{2} \mathrm{O}_{3}$ & $0,34 \%$ & $0,71-2,00 \%$ & \\
$\mathrm{Fe}_{2} \mathrm{O}_{3}$ & $0,00 \%$ & $0,36-1,47 \%$ & \\
$\mathrm{CaO}$ & $48,94 \%$ & $49,8-55,6 \%$ & Min. 48\% \\
$\mathrm{MgO}$ & $0,36 \%$ & $0,30-1,48 \%$ & Maks. 6\% \\
\hline $\mathrm{H}_{2} \mathrm{O}$ & $0,13 \%$ & & \\
\hline
\end{tabular}

4. Hasil analisis komposisi kimia conto D-79 pada koordinat $(0558034,9237787)$

Hasil analisis kimia nilai $\mathrm{SiO}_{2}, \mathrm{CaO}, \mathrm{MgO}, \mathrm{H}_{2} \mathrm{O}$ pada conto D-79 memenuhi syarat dalam kisaran yang telah ditentukan. Kadar $\mathrm{Al}_{2} \mathrm{O}_{3}$ dan $\mathrm{Fe}_{2} \mathrm{O}_{3}$, meskipun tidak masuk dalam kisaran Standar Baku untuk semen, menunjukkan bahwa conto D-79 dapat dimanfaatkan sebagai bahan baku semen karena memenuhi syarat dari PT. Semen Padang (Tabel 5).

Tabel 5. Pengklasifikasian Conto D-79

\begin{tabular}{cccc}
\hline $\begin{array}{c}\text { Komposisi } \\
\text { Kimia } \\
\text { Batuan }\end{array}$ & $\begin{array}{c}\text { Conto } \\
\text { D-79 }\end{array}$ & $\begin{array}{c}\text { Standar Bahan } \\
\text { Baku Semen } \\
\text { (Duda, 1976) }\end{array}$ & $\begin{array}{c}\text { Standar Bahan } \\
\text { Baku Semen } \\
\text { PT. Semen } \\
\text { Padang }\end{array}$ \\
\hline $\mathrm{SiO}_{2}$ & $1,57 \%$ & $0,76-4,75 \%$ & Maks. 5\% \\
$\mathrm{Al}_{2} \mathrm{O}_{3}$ & $0,49 \%$ & $0,71-2,00 \%$ & \\
$\mathrm{Fe}_{2} \mathrm{O}_{3}$ & $0,12 \%$ & $0,36-1,47 \%$ & \\
$\mathrm{CaO}$ & $52,81 \%$ & $49,8-55,6 \%$ & Min. $48 \%$ \\
$\mathrm{MgO}$ & $0,50 \%$ & $0,30-1,48 \%$ & \\
$\mathrm{H} \mathrm{H}_{2} \mathrm{O}$ & $0,13 \%$ & & Maks. 6\% \\
\hline
\end{tabular}

5. Hasil analisis komposisi kimia conto D-81 pada koordinat $(0558373,9237733)$

Conto D-81 memiliki kadar $\mathrm{SiO}_{2}, \mathrm{CaO}, \mathrm{Fe}_{2} \mathrm{O}_{3}$, $\mathrm{MgO}, \mathrm{H}_{2} \mathrm{O}$ yang sesuai persayaratan bahan baku semen. Melihat nilai $\mathrm{Al}_{2} \mathrm{O}_{3}$, maka conto D-81 dapat dimanfaatkan sebagai bahan baku semen karena memenuhi syarat dari 
Teknik, 38 (2), 2017, 97

PT. Semen Padang meskipun tidak masuk dalam kisaran Standar Baku(Tabel 6).

Tabel 6. Pengklasifikasian Conto D- 81

\begin{tabular}{cccc}
\hline $\begin{array}{c}\text { Komposisi } \\
\text { Kimia } \\
\text { Batuan }\end{array}$ & $\begin{array}{c}\text { Conto } \\
\text { D-81 }\end{array}$ & $\begin{array}{c}\text { Standar Bahan } \\
\text { Baku Semen } \\
\text { (Duda, 1976) }\end{array}$ & $\begin{array}{c}\text { Standar Bahan } \\
\text { Baku Semen PT. } \\
\text { Semen Padang }\end{array}$ \\
\hline $\mathrm{SiO}_{2}$ & $1,84 \%$ & $0,76-4,75 \%$ & Maks. 5\% \\
$\mathrm{Al}_{2} \mathrm{O}_{3}$ & $0,62 \%$ & $0,71-2,00 \%$ & \\
$\mathrm{Fe}_{2} \mathrm{O}_{3}$ & $0,36 \%$ & $0,36-1,47 \%$ & \\
$\mathrm{CaO}$ & $50,5 \%$ & $49,8-55,6 \%$ & Min. 48\% \\
$\mathrm{MgO}$ & $0,36 \%$ & $0,30-1,48 \%$ & \\
$\mathrm{H}_{2} \mathrm{O}$ & $0,12 \%$ & & Maks. 6\% \\
\hline
\end{tabular}

6. Hasil analisis komposisi kimia conto D-85 pada koordinat $(0558989,9237940)$

Conto D-85 memiliki kadar $\mathrm{CaO}, \mathrm{MgO}, \mathrm{H}_{2} \mathrm{O}$ yang sesuai persyaratan. Melihat nilai $\mathrm{Al}_{2} \mathrm{O}_{3}, \mathrm{SiO}_{2}$, dan $\mathrm{Fe}_{2} \mathrm{O}_{3}$, maka Conto D-85 juga memenuhi syarat dari PT. Semen Padang meskipun tidak masuk dalam kisaran Standar Baku untuk semen (Tabel 7).

Tabel 7. Pengklasifikasian Conto D-85

\begin{tabular}{cccc}
\hline $\begin{array}{c}\text { Komposisi } \\
\text { Kimia } \\
\text { Batuan }\end{array}$ & $\begin{array}{c}\text { Conto } \\
\text { D-85 }\end{array}$ & $\begin{array}{c}\text { Standar Bahan } \\
\text { Baku Semen } \\
\text { (Duda, 1976) }\end{array}$ & $\begin{array}{c}\text { Standar } \\
\text { Bahan Baku } \\
\text { Semen PT. } \\
\text { Semen } \\
\text { Padang }\end{array}$ \\
\hline $\mathrm{SiO}_{2}$ & $0,35 \%$ & $0,76-4,75 \%$ & Maks. 5\% \\
$\mathrm{Al}_{2} \mathrm{O}_{3}$ & $0,48 \%$ & $0,71-2,00 \%$ & \\
$\mathrm{Fe}_{2} \mathrm{O}_{3}$ & $0,27 \%$ & $0,36-1,47 \%$ & \\
$\mathrm{CaO}$ & $51,5 \%$ & $49,8-55,6 \%$ & Min. 48\% \\
$\mathrm{MgO}$ & $0,25 \%$ & $0,30-1,48 \%$ & \\
$\mathrm{H}_{2} \mathrm{O}$ & $0,10 \%$ & & Maks. 6\% \\
\hline
\end{tabular}

7. Hasil analisis komposisi kimia conto MB-93 pada koordinat $(0557735,9238106)$

Conto MB-93 memiliki kadar $\mathrm{CaO}, \mathrm{MgO}, \mathrm{H}_{2} \mathrm{O}$ yang sesuai persyaratan. Hasil analisis komposisi kimia juga menunjukkan kadar $\mathrm{Al}_{2} \mathrm{O}_{3}, \mathrm{SiO}_{2}$, dan $\mathrm{Fe}_{2} \mathrm{O}_{3}$ conto MB-93 memenuhi syarat dari PT. Semen Padang meskipun tidak masuk dalam kisaran Standar Baku untuk semen (Tabel 8).

Tabel 8. Pengklasifikasian Conto MB-93

\begin{tabular}{cccc}
\hline $\begin{array}{c}\text { Komposisi } \\
\text { Kimia } \\
\text { Batuan }\end{array}$ & $\begin{array}{c}\text { Conto } \\
\text { MB-93 }\end{array}$ & $\begin{array}{c}\text { Standar Bahan } \\
\text { Baku Semen } \\
\text { (Duda, 1976) }\end{array}$ & $\begin{array}{c}\text { Standar } \\
\text { Bahan Baku } \\
\text { Semen PT. } \\
\text { Semen } \\
\text { Padang }\end{array}$ \\
\hline $\mathrm{SiO}_{2}$ & $0,21 \%$ & $0,76-4,75 \%$ & Maks. 5\% \\
$\mathrm{Al}_{2} \mathrm{O}_{3}$ & $0,29 \%$ & $0,71-2,00 \%$ & \\
$\mathrm{Fe}_{2} \mathrm{O}_{3}$ & $0,21 \%$ & $0,36-1,47 \%$ & \\
$\mathrm{CaO}$ & $48.6 \%$ & $49,8-55,6 \%$ & Min. 48\% \\
$\mathrm{MgO}$ & $0,89 \%$ & $0,30-1,48 \%$ & \\
$\mathrm{H} \mathrm{O}$ & $0,03 \%$ & & Maks. 6\% \\
\hline
\end{tabular}

8. Hasil analisis komposisi kimia conto MB-95 pada koordinat $(0558126,9238153)$

Conto MB-95 memiliki kadar $\mathrm{Fe}_{2} \mathrm{O}_{3}, \mathrm{CaO}, \mathrm{MgO}$, $\mathrm{H}_{2} \mathrm{O}$ yang sesuai persyaratan bahan baku semen. Nilai
$\mathrm{Al}_{2} \mathrm{O}_{3}, \quad \mathrm{SiO}_{2}$, yang ditunjukkan dari hasil analisis komposisi menunjukkan bahwa Contoh MB-95 dapat dimanfaatkan sebagai bahan baku semen karena memenuhi syarat dari PT. Semen Padang meskipun tidak masuk dalam kisaran Standar Baku (Tabel 9).

Tabel 9. Pengklasifikasian Conto MB-95

\begin{tabular}{cccc}
\hline $\begin{array}{c}\text { Komposisi } \\
\text { Kimia } \\
\text { Batuan }\end{array}$ & $\begin{array}{c}\text { Conto } \\
\text { MB-95 }\end{array}$ & $\begin{array}{c}\text { Standar Bahan } \\
\text { Baku Semen } \\
\text { (Duda, 1976) }\end{array}$ & $\begin{array}{c}\text { Standar Bahan } \\
\text { Baku Semen } \\
\text { PT. Semen } \\
\text { Padang }\end{array}$ \\
\hline $\mathrm{SiO}_{2}$ & $0,08 \%$ & $0,76-4,75 \%$ & Maks. 5\% \\
$\mathrm{Al}_{2} \mathrm{O}_{3}$ & $0,47 \%$ & $0,71-2,00 \%$ & \\
$\mathrm{Fe}_{2} \mathrm{O}_{3}$ & $0,92 \%$ & $0,36-1,47 \%$ & \\
$\mathrm{CaO}$ & $53,7 \%$ & $49,8-55,6 \%$ & Min. 48\% \\
$\mathrm{MgO}$ & $0,63 \%$ & $0,30-1,48 \%$ & \\
$\mathrm{H}_{2} \mathrm{O}$ & $0,13 \%$ & & Maks. 6\% \\
\hline
\end{tabular}

9. Hasil analisis komposisi kimia conto P-84 pada koordinat (0557401, 9237508)

Conto P-84 memiliki kadar $\mathrm{Al}_{2} \mathrm{O}_{3}, \mathrm{Fe}_{2} \mathrm{O}_{3}, \mathrm{H}_{2} \mathrm{O}$ yang sesuai persyaratan. Melihat nilai kadar $\mathrm{SiO}_{2}, \mathrm{CaO}$ dan $\mathrm{MgO}$, maka Conto P-84 dapat dimanfaatkan untuk bahan baku semen karena memenuhi syarat dari PT. Semen Padang meskipun tidak masuk dalam kisaran Standar Baku (Tabel 10).

Tabel 10. Pengklasifikasian Conto P-84

\begin{tabular}{cccc}
\hline $\begin{array}{c}\text { Komposisi } \\
\text { Kimia } \\
\text { Batuan }\end{array}$ & $\begin{array}{c}\text { Conto } \\
\text { P-84 }\end{array}$ & $\begin{array}{c}\text { Standar Bahan } \\
\text { Baku Semen } \\
\text { (Duda, 1976) }\end{array}$ & $\begin{array}{c}\text { Standar Bahan } \\
\text { Baku Semen } \\
\text { PT. Semen } \\
\text { Padang }\end{array}$ \\
\hline $\mathrm{SiO}_{2}$ & $0,71 \%$ & $0,76-4,75 \%$ & Maks. 5\% \\
$\mathrm{Al}_{2} \mathrm{O}_{3}$ & $1,79 \%$ & $0,71-2,00 \%$ & \\
$\mathrm{Fe}_{2} \mathrm{O}_{3}$ & $1,43 \%$ & $0,36-1,47 \%$ & \\
$\mathrm{CaO}$ & $31,32 \%$ & $49,8-55,6 \%$ & Min. 48\% \\
$\mathrm{MgO}$ & $18,41 \%$ & $0,30-1,48 \%$ & \\
$\mathrm{H}_{2} \mathrm{O}$ & $0,07 \%$ & & Maks. 6\% \\
\hline
\end{tabular}

\section{Kesimpulan}

Berdasarkan komposisi kimia batuan dan persyaratan standar komposisi kimia bahan baku semen, batugamping di daerah Gandu memenuhi kriteria batugamping untuk bahan baku semen. Pada beberapa tempat, seperti pada P 84 dan D 65, ditemukan kandungan unsur $\mathrm{Mg}$ besar sehingga perlu dilakukan pengupasan. Hal ini perlu dilakukan mengingat kemungkinan prospek bahan baku semen didalam atau dibawah batugamping $\mathrm{P}$ 84 dan D 65 terdapat batugamping yang. Nilai $\mathrm{SiO}_{2}$, $\mathrm{Al}_{2} \mathrm{O}_{3}$, danFe $\mathrm{O}_{3}$ yang kurang memenuhi syarat tidak mempengaruhi dalam menetapkan layaknya atau tidaknya batugamping sebagai bahan baku semen dikarena unsur yang diperlukan dan yang perlu ditinjau adalah nilai $\mathrm{CaO}$ dan $\mathrm{MgO}$.

\section{Daftar Pustaka}

Atmojo, S.D. (2013). Masalah kependudukan di Indonesia sebagai negara berkembang. Tersedia di 
Teknik, 38 (2), 2017, 98

https://www.kompasiana.com/satrio-

dwiatmo/masalah-kependudukan-di-indonesiasebagai-negaraberkembang 5520acfba33311a24646d11c

Badan Perencanaan Pembangunan Daerah Pemerintah Kabupaten Blora (2016). Peraturan Bupati Blora Nomor 15 Tahun 2016 tentang Rencana Kerja Pemerintah Daerah Kabupaten Blora Tahun 2017. Tersedia

di
http://sipd.bangda.kemendagri.go.id/dokumen/uplo ads/rkpd_213_2017.pdf

Van Bemmelen, R.W. (1949), The Geology of Indonesia, Martinus Nyhoff, The Haque, Nederland.

Duda, W. H. (1976). Cement Data Book, ed-2 Mc. Domald dan Evans, London, 601 hal.

Embry, A.F., Klovan, J.E.(1971), A late Devonian reef tract on northeastern Banks Island, Northwest Territories, Bulletin of Canadian Petroleum Geology.
Gana, B.E., Prasetyadi, C., Triwibowo, B. (2012). Geologi dan Studi Facies Batugamping Bulu Daerah Jurangjero Kecamatan Jepon Kabupaten Blora Provinsi Jawa Tengah. Skripsi. Program Studi Teknik Geologi Fakultas Teknologi Mineral Universitas Pembangunan Nasional "Veteran" Yogyakarta.

Prasetya, Z. I. (2015). Keterdapatan Dolomit Pada Batugamping formasi bulu di desa Jurangjeru, Desa Gandu, Kabupaten Bogorejo, dan desa Kajar, desa Tegaldowo, Kec. Gunem, Provinsi Jawa Tengah. Thesis. Universitas Pembangunan Nasional Yogyakarta.

Pringgoprawiro, H. (1983). Biostratigrafi Dan Paleogeografi Cekungan Jawa Timur Utara : Suatu Pendekatan Baru. Institut Teknologi Bandung. 